\title{
Library Professionals and Social Network Sites: Use, Relevance and Challenges from University Libraries in Ogun State, Nigeria
}

\author{
Jerome Idiegbeyan-ose*, Goodluck Ifijeh**, Chidi Segun-Adeniran***, Michael Fagbohun**** \\ and Ugwunwa Esse***** \\ Covenant University, Nigeria - 103101 \\ E-mail: *jerome.idiegbeyanose@covenantuniversity.edu.ng; **goodluck.ifijeh@covenantuniversity.edu.ng; \\ ***chidi.segunadeniran@covenantuniversity.edu.ng; ****michael.fagbohun@covenantuniversity.edu.ng; \& \\ *****esse.ugwunwa@covenantuniversity.edu.ng
}

\begin{abstract}
The use of social network sites among library professionals in university libraries in Ogun State, Southwest Nigeria is investigated. The study population consisted of seventy-eight librarians in four universities in the state. Questionnaires (which was the instrument for data collection) were administered to the entire population, out of which 55 (representing $70.5 \%$ response rate) were filled, returned and analysed for the study. The study revealed that library professionals do make use of SNS. The most frequently visited SNS was Linkedln (58.2 \%). The respondents also indicated that they visited SNS for the purpose of connecting and collaborating with friends and colleagues, carrying out current awareness and reference services to library users, etc. Majority of the respondents $(94.5 \%)$ in the study further revealed that the greatest challenge to the use of social network sites was lack of social media skills. The first hypothesis tested in the study indicated that there was moderate positive significant relationship between device used for internet access and use of social network sites $\left(\mathrm{r}=.408^{* *}, \mathrm{~N}=55, \mathrm{p}<.002\right.$.). The second hypothesis revealed that there was no significant relationship between gender and use of SNS $(r=0$ $.157, \mathrm{~N}=55, \mathrm{p}>.05)$. The study was concluded with recommendations that library professionals should undergo training in social media skills.
\end{abstract}

Keywords: Library professionals, social network sites, university libraries, library users, Nigeria

\section{INTRODUCTION}

The advent of the internet in the $21^{\text {st }}$ century has revolutionise the operations and services of workplaces and professionals including libraries and librarians. Among the most influential tools of the internet in recent times are social network sites. The strength of the social network sites lies in their ability to enhance interactions and relationships among people. Thus, professionals could take advantage of social network sites (SNS) to meet and interact with clients as well as promote the operations of their workplaces. Suraweera ${ }^{1}$, et al., view social networking as a process of relationship building among a group of people with common interest. The SNS refer to the various internet platforms through which social networking is enhanced and sustained. The commonest SNS used in Nigeria are Facebook, twitter, MySpace, Youtube, Instalgram, Linkedln among others². Beyond social networking and relationships, these sites have become major tools for interaction and collaboration among professionals, organisations and their clients or customers. They have also become veritable tools in publicising, promoting and marketing products and services. Consequently, organisations and professionals have found the use of SNS inevitable in the quest for survival in very competitive environments. Libraries and librarians are not left out in this trend.
Ezeani \& Igwesi ${ }^{2}$ observed that Nigerian libraries have began to engage SNS as tools for rendering services as well as interacting with their users. For instance, Ezeani $\& \mathrm{Eke}^{3}$ posited that librarians in Nigeria are utilising SNS as tools to offer 'on the spot' library services to users. These services include real time chat with users through facebook and other electronic synchronising platforms. The opportunities and advantages provided by SNS have left Nigerian libraries and librarians with no choice than to adopt these tools if they must remain relevant in the $21^{\text {st }}$ century and beyond. The ease of communication, publicity and feedback mechanisms appear to be the selling points of SNS. Though the use of social network sites by Nigerian librarians generally has been documented in the past, it is observed that current issues and trends in the use of SNS among librarians in Universities in Ogun State, Nigeria have not been thoroughly covered. It is against this background that this study examines the use, relevance and challenges of SNS among librarians in Universities in Ogun State.

The use of SNS among professionals has become a global phenomenon. Librarians in Nigeria as professionals are not left out of this trend. SNS provide professionals including librarians with numerous benefits and advantages. However, the current trend in the use of SNS among librarians in Universities in Southwest Nigeria is unknown. 
This is particularly important because these librarians are facilitators who serve the information and research needs of the highest strata of the academia. There is therefore the need to investigate current trends, extent of use, identify challenges and proffer practical and workable solutions with a view to helping librarians in developing countries like Nigeria take full advantage of social network sites. It is for this reason that this study investigates the use of social network sites among library professionals in Universities in Ogun State, Nigeria.

\section{LITERATURE SURVEY}

\subsection{ICT, Social Media and Library}

The infiltration and inculcation of the utilisation of information and communication technologies in various sectors of the economy of nations especially education has brought about appreciable level of improvement in peoples' disposition towards new technologies. These dispositions have impacted positively on the modus operandi of professionals in the education sector, to which Library and Information professionals belong.

The expectations of clienteles' from information professionals have taken a totally new trend ${ }^{4}$ that is, it has gradually drifted from the usual manual and sometimes cumbersome means of carrying out service provision, to the use of information and communication technologies in service delivery. The use of these ICTs has brought about an obvious increase in the level of efficiency and effectiveness. This paradigm shift has not only brought about heightened level of effectiveness and efficiency but has also placed more responsibilities on information professionals to be more knowledgeable and savvy in the use of information and communication technologies. The ICT platform especially the internet, has provided library users with the opportunity to access information services and resources through virtual means; a reasonable number of library users now have access to the library's electronic resources. The application of ICT to library and information practice has brought about the existence of the term 'library without walls'. Similarly Ezeani \& Igwesi opined that the concept of the library being a physical place containing books for consultation is rapidly changing to a cyberspace that allows for access, interaction and contribution to existing knowledge.

The use of ICT has also enhanced various services in the library such as circulation services, reference services, serials management etc. Librarians can now carry out specialised services such as selective dissemination of information, current awareness services, reservations, etc. through the use of these ICTs. Some of the important and creative platforms for libraries and librarians' interactions with their clients are SNS. Instant messages, e-mails and posting of information on social network sites are now being used for carrying out library services in the library.

The SNS Web 2.0 platforms because there is usually a give and receive relationship between the sender and the receiver through the internet. In Nigeria, the use of SNS helps professionals and clients to make public profiles and foster relationships with each other through forums, chatrooms, etc. ${ }^{5}$

Boyd \& Ellison ${ }^{6}$ gave an in depth definition of social network sites as 'web-based platforms that allow individuals to create and manage a public or semi-public profile within a bounded system, articulate a list of other users with whom they share a connection, and view and traverse their list of connections and those made by others within the system'.

The underlining feature of SNS is that it allows for the establishment and building of interactions. Similarly Trampedach ${ }^{7}$ defined social network sites as sites that allows a user to create a profile, set up an account to create a digital representation of themselves; select other members of the site as contacts or connections, communicate and engage with these users which automatically creates a social graph and use an interface (API) to build applications.

With the introduction of SNS into library and information services, there are some activities that can be carried out in the library which couldn't have been possible before and all this happens using the internet as a platform; hence Ezeani \& Igwesi ${ }^{2}$ noted that social media have become very important and has positively impacted the library profession tremendously in Nigeria. They posited that through the help of connection of networks, messages in form of text, pictures, audio and video can be transferred between individuals or among people in a group. It is in the same vein that library and information professionals make use of this social media to communicate with clienteles and vice versa. Eke, Omekwu \& Odoh $^{8}$ unequivocally noted that 'the universality of the social media or SNS has conferred on it its present popularity and importance which is immeasurable as compared with other media'. It is the result of this universality that allows for the interaction between or among librarians and their clienteles. The thrilling fact about the use of SNS or social media is that they are not only being used on the computer system but also it could be used on the mobile phones and other devices that have internet access.

\subsubsection{Hypotheses}

The following hypotheses were raised and were tested at 0.05 level of significant:

\section{H01: There is no significant relationship between the type of device used and social network site usage by librarians.}

H02: There is no significant relationship between gender and use of SNS.

\subsection{Social Network Sites by Library Professionals}

Library and information services are usually carried 
out by library Professionals whose main functions are to acquire, organise, disseminate and store information embedded in various forms of information resources in order to satisfy the varying information needs of their clientele. Idiegbeyan-ose, Ilo \& Isiakpona' noted that 'a properly equipped library is a necessity when considering the intellectual, moral and spiritual development of library users'. However, these dynamic responsibilities of dissemination and managing information by professionals in libraries and information centres in Nigeria have been made more effective through the use of social media or SNS. Quadri \& Idowu ${ }^{10}$ in their study on the use of social media for information dissemination by librarians in nigeria corroborated this fact when they observed that $73 \%$ of librarians make use of social media for current awareness services, $63.3 \%$ for reference services, $56.7 \%$ for selective dissemination of information and about $58 \%$ for library orientation

Some of the ways in which SNS have enhanced library and information services include ${ }^{12}$ :

Reference Services: It has been made easy through the use of social media. For instance through the platform of Facebook, a user can have direct access to the reference librarian and ask queries and is sure to get response immediately or almost immediately. The response to queries could also be made richer through audio responses on platforms like facebook. The Skype platform could even give the user and librarian the opportunity to see each other and interact better even without coming to the library.

Current Awareness Services: Utilisation of social media or SNS in LIS has brought about ease also in the process of carrying out current awareness services. Library professionals can simply place information on new arrivals, orientation programmes, electronic resources and online resources available in the library on the sites. Most library users who will ordinarily not read such information would be interested in them now because they are publicised on social media and most of the library patrons will always visit these social media ${ }^{2}$.

Reservations: In the aspect of reservations and renewal of loans, instead of coming to the physical library building, the library user can send messages to the circulation librarian through any of the most convenient social media; he can even go as far as making a call also through any of the media platform like Skype or facebook.

User Education Programmes: This service can be done virtually and hosted on the library's website or even placed on YouTube for users to have access. This saves library profession and clientele the rigours of organising orientation programmes within the four walls of the library. With the use of social media, orientation and user education programmes can be done virtually.

Marketing of the Library Services: Marketing of library services is also made easy through the use of social media platforms. Pictures of the library facilities, various sections, available resources and professionals can be placed on the library's facebook page or on Flickr. This will entice reluctant library users to maximise these available resources.

Selective Dissemination of Information: This specialised library service could also be enhanced through the use of platforms like LinkedIn. This is because LinkedIn captures the area of specialisation of the user and this allows the librarian to source for resources that will benefit the clientele. The value added to the services of the library by the use of social media cannot be overemphasised hence Taylor \& Francis ${ }^{11}$ noted some advantages of adopting social media in the process of carrying out library housekeeping functions. Some of these advantages include:

(a) It ensures feedback from users thereby enhancing library services evaluation

(b) It increases usage of library's content

(c) Cheap publicity of events, programmes and services

(d) To ensure connection and interaction with other librarians

(e) It requires little or no training as the interfaces involved are very user friendly

\subsection{CHALLENGES}

It is pertinent to note that there are some challenges involved with the use of SNS in libraries. Ifijeh ${ }^{12}$ identified some of these challenges as:

Copyright issues: It is a common challenge when making use of social media to disseminate information and this is not restricted to information disseminated in print format alone but it also cuts across information disseminated in audio and video format. Librarians may infringe on some authors' copyright if they are not well knowledgeable in the process of making information accessible on social media, hence it is paramount that information professionals even in the bid to satisfy information needs should not go beyond the dictates of the copyright law.

Skills: Technical competence is a point that cannot be overlooked when using SNS and this could sometime pose as a challenge as some library professionals may not possess needed skill to function effectively in this area. Taylor \& Francis $^{11}$ reiterated that high level of expertise is required when using social media; they noted that in some instances the library professional may require skills for customising applications that aid in the process of accessing online catalogs.

Cost: Cost of carrying out library services using social network sites could be enormous. The cost here includes cost of purchasing and maintaining needed infrastructure and equipment, remunerations for technical staff, cost of regular training, cost of bandwidth, electricity, etc.

Time consuming: Use of social media or SNS for carrying out library services can be time consuming; this is because 
any information professional that wants to be effective and efficient enough in quenching the information thirst of his clientele would need to spend a lot of time on the internet. Clients could get frustrated if they send in a query and do not get the needed response in good time; hence to avoid this, the librarian would always have to spend hours on the internet answering queries

Technophobia and Technostress: Despite the level of infiltration of ICTs in library and information profession today some information professionals still have that inert fear of technology. They would rather stick to the manual means of carrying out library services. Also there is the challenge of technology related stress; information professionals that make use of ICT tools for a long period of time usually experience this kind of stress. Isiakpona \& Adebayo $^{13}$ explained that technostress is usually caused by the use of obsolete technology, power fluctuation, slow network, poor sitting position, poor computer proficiency skill, etc.

\section{OBJECTIVE}

The general objective of the study is to investigate use, relevance and challenges of social network sites among University library professionals in Ogun State, Nigeria.

The specific objectives are to:

(a) Find out if the librarians in University Libraries in Ogun State use social network sites

(b) Find out how often the librarians in the libraries under study use social network sites

(c) Find out the types of social network sites use by librarians in the libraries under study

(d) Ascertain the types of devices that the librarians use to access social network sites

(e) Find out the purpose of use of social network sites by librarians in the libraries under investigation

(f) Understand the challenges of social network sites usages by librarians in the libraries under study

\section{METHODOLOGY}

The study adopted a case study approach. Seventyeight librarians in four universities in Ogun State were used as population for the study.

Table 1 four shows chosen the institutions were based on proprietorship. One each is owned by the Federal and State Governments respectively while two are owned by private bodies. Total enumeration (census) method was used as all the professional librarians is in the selected universities were used for the study. Questionnaire was the research instrument to collect data from the respondents. The questionnaires were administered to the entire population in their places of work and a total of 55 questionnaires (representing $70.5 \%$ ) were completed and returned. The data was analysed using the Statistical
Package for the Social Sciences (SPSS).

\section{ANALYSES AND INTERPRETATION}

$69.1 \%$ librarians were females while their counterparts $17(30.9 \%)$ were male. This showed that majority of librarians in the libraries under study were females 18 $(32.7 \%)$ of the respondents were Assistant Librarian, 12 (21.8 \%) were Librarian I, 11 (20.0\%) were Librarian II and Senior Librarian, while just $3(5.5 \%)$ were Principal Librarian. Majority 24 (43.6\%) of the respondents had

Table 1. List of institutional under survey

\begin{tabular}{llcc}
\hline Name of institution & Proprietor & $\begin{array}{l}\text { Number of } \\
\text { librarians }\end{array}$ & $\begin{array}{l}\text { Questionnaires } \\
\text { returned }\end{array}$ \\
\hline $\begin{array}{l}\text { University of agri- } \\
\text { culture (FUNAAB) }\end{array}$ & $\begin{array}{l}\text { Federal } \\
\text { Government }\end{array}$ & 25 & 16 \\
$\begin{array}{l}\text { Bells university of } \\
\text { technology }\end{array}$ & Private & 9 & 9 \\
$\begin{array}{l}\text { Covenant university } \\
\text { Tai solarin univer- } \\
\text { sity }\end{array}$ & $\begin{array}{l}\text { Private } \\
\text { State Gov- }\end{array}$ & 25 & 14 \\
Total & ernment & & 16 \\
\hline
\end{tabular}

6-10 years working experience, 15 (27.3\%) had 1-5 years working experience, $19(20.0 \%)$ had $11-15,4$ $(7.3 \%)$ had $16-20$ while $1(1.8 \%)$ had 21 years and above working experience.

\subsection{Use of Social Networking Sites}

Figure 1 reveals that the most frequently visited social network site by the respondents under study is Linkedln $-58.2 \%$ visit the site daily. This is followed by twitter (41.8\%), Facebook (40\%), flickr (32.7\%), MySpace (25.5\%), HiS (12.7\%) and Instant Messaging $(9.1 \%)$. It also shows that the respondents rarely visited Wikis.

\subsection{Frequency of Use of SNS}

Figure 2 shows that the library professionals under study do visit and make use of social network sites. The sites they visit include facebook, twitter, instant messaging, $\mathrm{Hi}^{5}$, flikr, linkedln, RSS feeds, youtube among others.

\subsection{Devices Used to Access SNS}

Figure 3 reveals the frequency distribution of respondents' responses of the kinds of devices they use to access social network sites. The results show that $92.7 \%$ use iPad, $90.9 \%$ use laptops and desktops to access social sites, $54.5 \%$ Android, $52.7 \%$ use BackBerry, and $9.1 \%$ Tablets. The findings shows that majority of respondents use divers devices to accede social sites, especially iPad, Desktop, Laptop, Android and Black Berry.

\subsection{Purpose for Use of SNS}

Figure 4 outlines respondents' responses to their 


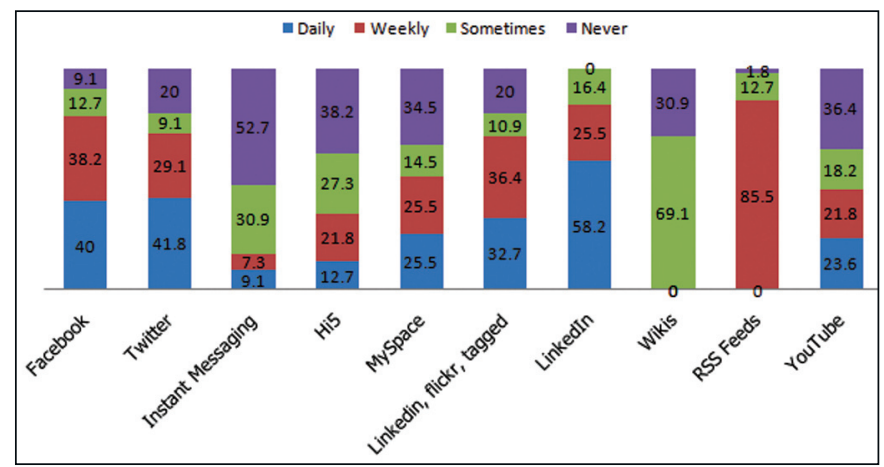

Figure 1. Use of the SNS.

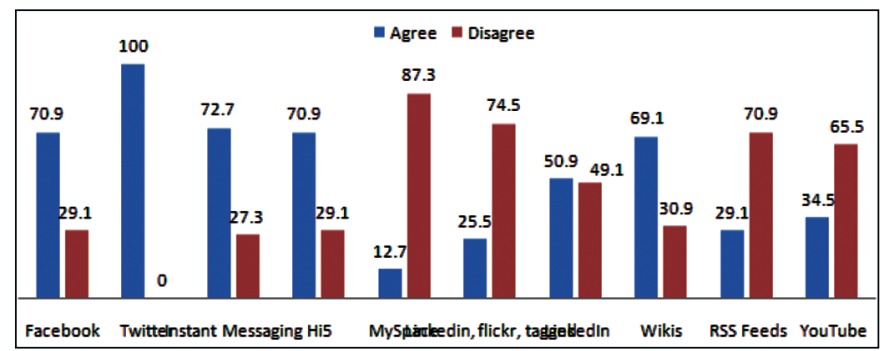

Figure 2. Frequency of use of SNS.

purpose of visiting SNS. Majority (90\%) indicated that they visited SNS to make new friends and current awareness, $80 \%$ indicated for professional usage and reference services, $60 \%$ to connect with friends and to collaborate with colleagues, while $30 \%$ indicated for research.

\subsection{Challenges Encountered in the use of SNS}

Figure 5 reveals that lack of social media skills $(94.5 \%)$ posed as the greatest challenge to library professionals use of social media network sites. Other challenges include digital divide $(83.6 \%)$, lack of funds

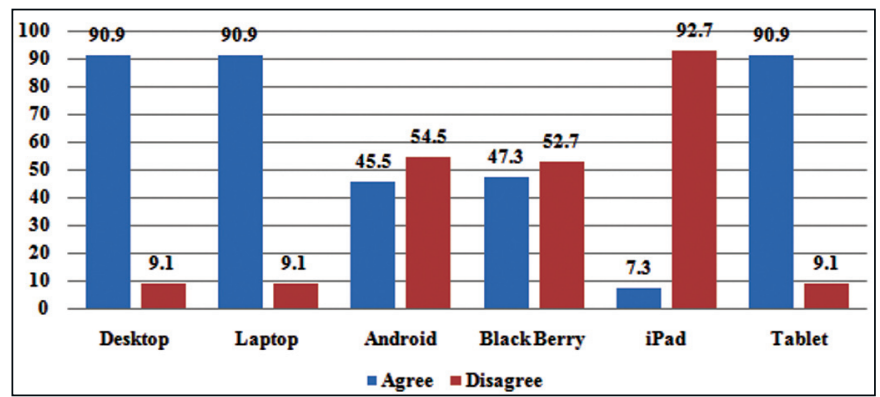

Figure 3. Types of device use to access SNS.

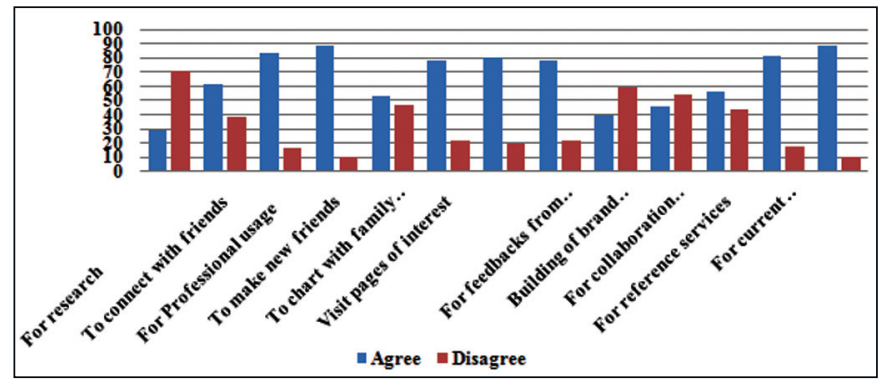

Figure 4. Libraries purpose of SNS.
$(83.6 \%)$, privacy and security concerns $(83.6 \%)$, low bandwidth (76.4\%), Erratic power supply (76.4\%)

\section{Hypotheses}

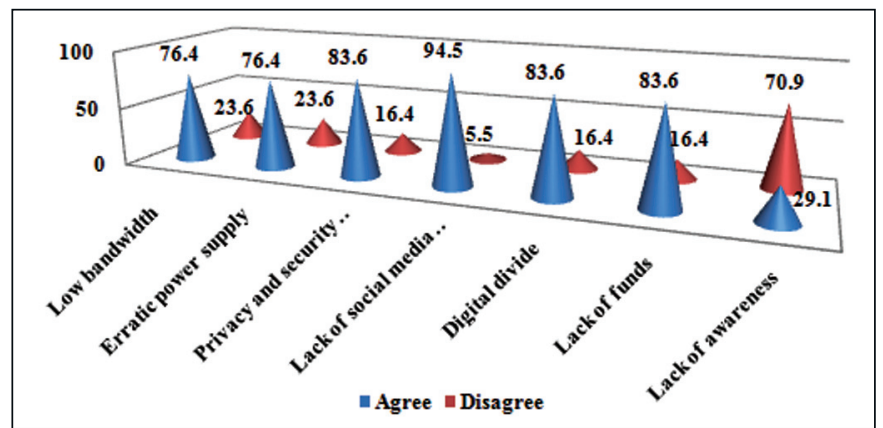

Figure 5. Chellenges encountered in the use ofsocial network sites

H01: There is no significant relationship between the device use and SNS usage by librarians

Table 3 revealed that there is moderate positive significant relationship between device and use of social networking sites among librarians in Ogun State Nigeria $\left(\mathrm{r}=.408^{* *}, \mathrm{~N}=55, \mathrm{p}<.002\right.$.). As shown in Table, the Pearson Correlation Coefficient of 0.408 shows a mild positive correlation between types of device and use of SNS. This implies that the kind of devices use by librarians affects or influence their motivation to visits SNS.

H02: There is no significant relationship between gender and use of SNS

Table 3. Relationship between device used to access the internet and SNS usage

\begin{tabular}{lllllll}
\hline Variable & Mean & Std. deviation N & R & P & Remark \\
\hline Device & 14.8545 & 3.41792 & 55 & $.408^{* *}$ & & n.S
\end{tabular}

0.002

Use of $\quad 25.6909 \quad 4.50051 \quad 55$ SNS

Table 4 shows that there is no significant relationship between gender and use of social networking sites due to the high $\mathrm{p}$-value of $0.254(\mathrm{r}=.157, \mathrm{~N}=55, \mathrm{p}$ $>.05)$. The null hypothesis is therefore rejected and the

Table 4. Relationship between gender and use of SNS

\begin{tabular}{lllllll}
\hline Variable & Mean & $\begin{array}{l}\text { Std. } \\
\text { deviation }\end{array}$ & N & R & P & Remark \\
\hline Gender & 1.69 & 0.466 & 55 & & & n.S \\
& & & & & & 0.254 \\
& & & & & & \\
& & & & 0.157 & & \\
$\begin{array}{l}\text { Use of } \\
\text { SNS }\end{array}$ & 25.6909 & 4.50051 & 55 & & & \\
\hline
\end{tabular}


alternative hypothesis accepted. This implies that both male and female librarians use social networking sites equally. This equality among male and female librarian might be due to the minimal level of exposure to ICTs gadgets and access to computer systems in their various place of work.

\section{RESULTS AND FINDINGS}

(a) Library professionals make use of SNS ranging from Linkedln, facebook, twitter, Myspace, etc. Frequency of use ranged from daily, weekly etc.

(b) The most frquently visited SNS by the respondents is Linkedln. Linkedln is a SNS that serves as a veritable platform for linkage and collaboration with fellow professionals. Other frequently visited SNS include facebook, twitter, etc.

(c) Majority of the respondents $(65.5 \%)$ do not use you tube SNS even though this site contain important information resources for teaching and research.

(d) Mobile devices like ipads, anthroids, blackberries and tablets were the major devices used by library professionals to access SNS. These devices have easy and cheaper access to the internet through mobile telephony technology using subscriber identity module (SIM) cards.

(e) The SNS are used to make new friends, connect and collaborate with colleagues, carry out current awareness and other professional services like reference.

(f) The greatest challenge to library professionals' use of SNS is lack of social media skills. Other challenges include low bandwidth, erratic power supply, lack of funds, etc.

(g) There was a moderate positive significant relationship between the device used by the respondents and their social network sites usage $\left(\mathrm{r}=0.408^{* *}, \mathrm{~N}=55\right.$, $\mathrm{p}<0.002$.).

(h) There was no significant relationship between gender of respondents and use of SNS. ( $\mathrm{r}=0.157, \mathrm{~N}=55$, $\mathrm{p}>0.05$ ).

\section{CONCLUSION AND RECOMMENDATIONS}

(a) A course on use of social media for library services should be introduced in library schools in Nigeria. This will help to build social media skills in student librarians even before they leave school. They will find the skills useful in their professional practice.

(b) Library professionals who are already out of school should do in-house training on social media skills. Library managements should invite social media professionals to help train their staff. The Nigeria Library Association and The Librarians Registration Council of Nigeria (LRCN) should organise workshops on building social media skills for librarians.

(c) Library professionals should look for alternative source of fund to train themselves on skills acquisition; they should apply for both local and international sponsorship to international organisations such as UNESCO, IFLA, Carnegie Cooperation of New York, among others, to attend workshops and conferences on skills acquisition

(d) Relevant authorities should provide necessary and adequate funds for libraries to acquire ICT facilities that will enable social media interactions between librarians and users. ICT facilities are very expensive to acquire. Funds must be made available for libraries to be well equipped to provide adequate and prompt services in the competitive world of the 21 st century.

(e) Telecommunication and multinational corporations should be encouraged by Government to embark on corporate social responsibility activities in libraries especially in the area of ICT facilities provision.

(f) Library professionals need to increase the frontiers of their social network sites use in carrying out professional services. Librarians should not use social network sites to connect and collaborate with colleagues and friends alone. There is a need for library professionals to take advantage of SNS to expand professional services to users.

(g) Library professionals should improve their use of social network sites especially the use of you tube as majority of the respondents $(65.5 \%)$ don't use this important site for their research and teaching.

\section{REFERENCES}

1. Suraweera, S.N., et al. Value of social networking in libraries and information organizations in Asia and Oceania. World library and information Congress, 76th IFLA General Conference and Assembly. 10-15 August 2010, Gothenburg, Sweden.

2. Ezeani, C.N. \& Igwesi, U. Using social media for dynamic library service delivery: The Nigeria experience. Lib. Phil. and Pract. (e-journal), 2012. Paper 814. http://digitalcommons.unl.edu/libphilprac/814.

3. Ezeani, C.N. \& Eke, H.N. Transformation of Web 2.0 into Lib 2.0 for Driving Access to Knowledge by Academic Libraries in Nigeria. In 48th National Conference and Annual General Meeting of the Nigerian Library Association. Theme: Knowledge Management for National Development, 2011. HEBN Publishers, Ibadan, p. 80.

4. Hashim, L. \& Mokhar, W. Preparing new era librarians and information professionals: Trends and issues. Inter. J. of Human. and Soc. Sci., 2012, 2(7), 15156.

5. Beal, V. SNS, 2016. http://www.webopedia.com/ TERM/S/social_networking_site.html (accessed on 9 June 2016).

6. Boyd, D.M. \& Ellison, N.B. SNS: Definition, history 
and scholarship. J. of Com.-Mediated Comm., 2007, 13(1), 210-30.

7. Trampedach, T. (n.d.). Introduction to social networking. http://edidaktik.at/fachtagung08/trampedach_intro-tosocial-networking.pdf (accessed on 8 June 2016).

8. Eke, H.N.; Omekwu, C.O. \& Odoh, J.N. The use of SNS among the undergraduate students of University of Nigeria, Nssuka. Lib. Phil. and Pract. (e-journal), 2014 Paper 1195. http://digitalcommons.unl.edu/ libprac/1195.

9. Idiegbeyan-ose, Ilo, Promise \& Isiakpona, C. The 21 st century library and information services as a veritable strategy for the enhancement of teacher education. In Handbook of Research on Enhancing Teacher Education with Advanced Instructional Technologies, edited by Ololube, N.P.; Kpolovie, J.P. and Makewa, L.N. IGI Global, 2015, pp. 20-33.

10. Quadri, G. \& Idowu, O. The use of social media for information dissemination by librarians in Nigerian universities. Paper presented at $15^{\text {th }}$ Annual IS Conference, University of Zululand, South Africa, September, 2014.

11. Taylor \& Francis Group. Use of social media by the library: Current practices and future opportunities. A White Paper from Taylor \& Francis, 2014.

12. Ifijeh, G. Adoption of digital preservation methods for theses in nigerian academic libraries: Applications and implications. The J. of Acad. Lib., 2014, 40, 399-404.

13. Isiakpona, C. \& Adebayo, O. The impact of technostress on librarians: A survey of Covenant University Library. The Information Manager, Ahmadu Bello University, Zaria, 2011, 11(1\&2). http://www.ajol. info/index.php/tim/article/view/83640.

\section{Contributors}

Mr. Jerome Idiegbeyan-ose is presently Principal Librarian and Head of Technical Services Section, Centre for Learning Resources, Covenant University Canaan Land Ota, Ogun State, Nigeria. He holds Bachelor and Master degrees in Library and Information Science and presently a doctoral students. He has written articles in both local and international journals. He is a certified Librarian of Nigeria (CLN) by the Librarian Registration Council of Nigeria (LRCN). He is a Member Nigerian Library Association, Member Cataloguing and Classification Section of the Nigerian Library Association, Member Research and Development Network (International Research and Development Institute).

Mr. Goodluck Ifijeh is a Senior Librarian at the Centre for Learning Resources, Covenant University, Ota, Ogun State, Nigeria. He obtained his MLIS degree from the University of Ibadan, Nigeria. He is a certified Librarian with the Librarians Registration Council of Nigeria and member of the Nigerian Library Association. He has published paper in local and international journals. He has also contributed chapters in books published within and outside Nigeria.

Mrs. Chidi Segun-Adeniran is presently working as Librarian in the Technical services Unit of the Centre for Learning Resources, Covenant University, Ota, Nigeria and is a Certified Librarian of Nigeria. She is a First Class graduate of the Department of Library, Archival and Information Studies, University of Ibadan. She holds a Master of Library and Information Studies from the same institution. She has published numerous articles in both local and international journals. She is an astute scholar whose research interest covers areas such as information technology, bibliometrics, electronic information resources and copyright.

Mr. Fagbohun, Michael Opeoluwa holds a Bachelor Degree in Library and Information Science from Tai Solarin University of Education, Ogun State and Masters Degree in Library and Information Science (MLS) from University of Ibadan, Nigeria. He is a Digital Serials Librarian, Centre for Learning Resources, Covenant University, Otag, Ogun State Nigeria. His research areas includes: Digital services library service, cloud computing, library user satisfaction and quality control, e-discovery and knowledge management, information literacy skills and information access to disadvantaged individuals.

Mr. Ugwunwa Chinyere Esse holds a Masters Degree in Information Science from the University of Ibadan. She is presently a Librarian I at Centre for Learning Resources, Covenant University. Her research interest include: Library automation, document digitisation, e-learning, e-resources, Web 2.0, e-learning, user education and user behaviour. 